\title{
PERGESERAN TIPOLOGI HUKUM DI INDONESIA
}

\author{
SHIFTING LEGAL TYPOLOGY IN INDONESIA
}

Senja Nasril, Nur Intan Akuntari

Fakultas Hukum Universitas Sriwijaya, Jl. Srijaya Negara, Palembang, Indonesia

Email: senjjanaszril@gmail.com, akuntarinurintan@gmail.com

\begin{abstract}
ABSTRAK
Perkembangan tipologi hukum di Indonesia akan selalu berubah-ubah setiap waktunya, ditambah lagi dalam perumusan suatu undang-undang sangat dipengaruhi kepentingan partai politik tertentu karena yang merumuskannya adalah anggota legislatif. Penelitian ini akan mengkaji bagaimana perkembangan hukum di Indonesia serta mengetahui bagaimana tipologi hukum di Indonesia. Hasil penelitian ini, penggunaan hukum peninggalan Belanda hanya untuk agar tidak adanya kekosongan hukum. Hukum di Indonesia sangat dekat dengan tipologi hukum represif, dimana pembentukan dan penerapan hukum banyak dipengaruhi oleh kepentingan politik. Bukan saja menciptakan rasa tidak adil terhadap masyarakat dan adanya hukum seperti itu juga tentu akan menjadi momok bagi kalangan masyarakat itu sendiri
\end{abstract}

Kata Kunci: Pancasila, Hukum, Indonesia, Tipologi Hukum. 


\begin{abstract}
The development of legal typology in Indonesia will always change from time to time, plus the formulation of a law is strongly influenced by the interests of certain political parties because those who formulate it are members of the legislature. This research will examine how the development of law in Indonesia. As well as knowing how the typology of law in Indonesia. The results of this study, the use of Dutch heritage law is only to avoid a legal vacuum. Law in Indonesia is very close to the typology of repressive law, where the formation and application of law is heavily influenced by political interests. Not only does it create a sense of injustice to the community and the existence of such a law will certainly be a scourge for the community itself.
\end{abstract}

Keyword: Pancasila, Law, Indonesia, Legal Typology.

\title{
PENDAHULUAN
}

Sesuai dengan yang termuat pada Pasal 1 Ayat 3 Undang-Undang Dasar 1945 (selanjutnya disebut UUD 1945) yang diamandemen terakhir kali dan disahkan pada 10 November 2001, bahwa negara Indonesia adalah negara hukum. Hukum menjadi sebuah penegasan bahwa segala aspek kehidupan di Indonesia dalam sosial kemasyarakatan, kenegaraan serta pemerintahan berlandaskan hukum. Hukum menjadi landasan berjalannya sendi-sendi pemerintahan dalam mengatur masyarakat agar terciptanya ketertiban sosial. UUD 1945 telah mengamanatkan supaya dalam penegakan hukum di Indonesia menggunakan prinsip keseimbang, baik dalam menegakkan keadilan substansial maupun konsepsi hukum itu sendiri. Lebih dalam lagi, UUD 1945 juga menegaskan mengenai asas manfaat hukum, yaitu dimana asas tersebut yang menghendaki supaya dalam penegakan hukum tentunya berguna, bermanfaat, serta tidak menumbuhkan dan atau memunculkan kemudharatan bagi setiap masyarakat, bangsa, dan negara (Moh Mahfud MD, 2009: 284).

Jimly Asshiddiqie juga mengungkapkan, bila aturan dimengerti secara kaku serta sempit yang artinya hanya sebatas peraturan perundang-undangan saja, maka artian dari negara hukum yang dikembangkan menjadi bersifat sempit dan tentunya terbatas serta sangat sulit untuk menjamin keadilan substantive. Sebab itu, istilah 'the rule of law' yang disampaikan Friedman juga dikembangkan dengan istilah 'the rule of just law' guna adanya kepastian bahwa dalam pengertian bersama tentang 'the rule of law' termuat maksud yang 
tidak hanya sekedar memfungsikan peraturan perundang-undangan dalam arti sempit tetapi memberikan keadilan yang lebih esensial. Dengan begitu, walaupun istilah yang dipakai tetap 'the rule of law', pengertian yang bersifat luas itulah yang diharapkan dicakup dalam istilah 'the rule of law' yang dipergunakan dalam menyebut konsepsi perihal negara hukum di zaman modern ini (Jimly Asshiddiqie, 2005: 29).

Reformasi sangat berdampak bagi perkembangan masyarakat dalam konteks kebangsaan serta dalam sistem ketatanegaraan Indonesia. Dengan telah terjadinya amandemen UUD 1945, pengertian negara hukum secara gamblang serta dengan tegas dituliskan dan termaktub pada batang tubuh UUD 1945 yang sebelum hanya ada pada penjelasan UUD 1945 saja. Hal ini menjelaskan dan mempertegas komitmen bersama bahwa Indonesia ialah, bukan negara yang otoriter dan Indonesia adalah hukum yang demokratis.

Pada amandemen ketiga yang disahkan pada 2001 yang lalu, dibuat juga sebuah lembaga peradilan yang berfungsi untuk mengawal konstitusi Indonesia, yaitu Mahkamah Konstitusi. Dengan dibentuknya lembaga negara di bidang kekuasaan kehakiman merupakan juga pertanda penegasan negara, bahwa negara kita menganut paham negara hukum yang menganut paham konstitusionalisme. Pada kondisi ini, maka bisa kita dipahami bersama bahwa bukan hanya rakyat yang terlibat dalam persoalan hukum saja yang dapat diadili sesuai dengan hukum yang ada, tetapi pula pemerintah dan lembaga negara, serta undang-undang yang bertentangan dengan UUD 1945 juga bisa dibawa kedalam lembaga peradilan. Artinya, salah satu tugas utama Mahkama Konstitusi ialah menjaga supaya tidak ada undang-undang yang telah disahkan bertentangan dengan UUD 1945. Dengan demikian setiap aturan dan undang-undang yang dibuat dan disahkan oleh pihak yang mempunyai wewenang harus dan wajib tidak boleh bertentangan terhadap UUD 1945 sebagai landasan tertinggi negara (Utrecht, 1962: 9).

Dalam setiap perkembangan hukum yang terjadi, maka bisa saja tipologi hukum yang berjalan di masyarakat tersebut ikut berubah, hal ini biasanya seringkali dipengaruhi berbagai faktor. Contohnya saja misalnya faktor yang ditentukan oleh pemegang kekuasaan pada saat itu, penguasa bisa saja menggunakan kekuasaannya dalam melakukan pembentukan perundang-undangan, kemudian faktor penegak hukum itu sendiri, sebagai penegak hukum bukan tidak mungkin dalam menegakan hukum lebih berpihak pada orang yang mempunyai kekuasaan dan justru lebih tajam kebawah dalam artian hukum hanya berlaku untuk rakyat kecil saja.

Perkembangan hukum dan tipologi hukum di Indonesia sendiri merupakan suatu yang menarik untuk dipelajari karena akan selalu berubah-ubah setiap waktunya, ditambah lagi 
dalam perumusan undang-undang adalah anggota legislatif yang notabenenya adalah para pengurus partai politik bukan tidak mungkin dalam perumusan suatu undang-undang sangat dipengaruhi kepentingan partai politik tertentu. Berangkat dari hal inilah yang melandasi kenapa penulis tertarik dengan perkembangan hukum dan tipologi hukum di Indonesia dan mendapatkan dua rumusan masalah dibawah ini. Berdasarkan latar belakang yang telah dijelaskan dan disampaikan di atas, sangat menarik untuk dibahas dalam bentuk jurnal, maka dapat dirumuskan permasalah yang ada sehubungan dengan latar belakang yang telah disampaikan yaitu sebagai berikut; Pertama, Bagaimana perkembangan hukum di Indonesia ? Kedua, Bagaimana tipologi hukum di Indonesia?

\section{METODE PENELITIAN}

Penelitian ini adalah penelitian hukum normatif. Penelitian ini memakai pendekatan perundang-undangan serta pendekatan kasus. Jenis data dan bahan-bahan hukum yang pakai adalah bahan hukum primer, sekunder, serta tersier. Bahan hukum primer ialah bahan hukum yang bersifat autoritatif artinya memiliki otoritas dalam hal bahan-bahan hukum primer merupakan bahan hukum yang terdiri dari perundang-undangan, catatan-catatan resmi dan atau risalah dalam pembuatan peraturan perundang-undangan dan putusan pengadilan. Bahan hukum sekunder adalah bahan-bahan hukum yang memberikan petunjuk serta penjelasan perihal bahan hukum primer. Bahan hukum sekunder ialah bahan hukum yang berasal dari buku-buku, literatur yang berkaitan dalam penelitian yang sedang diteliti, dan hasil penelitian hukum serta hasil karya ilmiah dari kalangan ilmuwan hukum. Bahan Hukum Tersier adalah bahan-bahan hukum yang memuat petunjuk serta penjelasan terhadap bahan hukum primer dan bahan hukum sekunder, contohnya kamus hukum, kamus bahasa Indonesia, serta lainnya. Dengan begitu penulis dalam memakai bahan-bahan hukum tersier ini akan berpedoman pada tulisantulisan, artikel, buku, dan jurnal serta dokumendokumen yang berhubungan dengan judul penelitian ini. Analisis yang dipakai dalam penelitian ini ialah kualitatif serta penarikan kesimpulan secara deduktif.

\section{HASIL PENELITIAN DAN PEMBAHASAN \\ Perkembangan Hukum di Indonesia}

Sistem hukum Eropa, aturan tentang agama, dan hukum adat sangat mempengaruhi hukum di Indonesia. Contohnya saja, baik hukum pidana maupun perdata masih berbasis hukum peninggalan Belanda sedangkan untuk hukum keluarga sendiri masih menggunakan hukum dan aturan yang berlandaskan agama. Semua ini tidak terlepas dari masa lalu Indonesia yang pada dahulu dikenal dengan istilah nusantara yang sebagian besar adalah wilayah jajahan Hindia-Belanda. 
Ada beberapa periode perkembangan sejarah hukum di Indonesia antara lain: Pertama, Periode Kerajaan, periode ini adalah dimana Indonesia masih terbagi menjadi kerajaan-kerajaan dan lebih dikenal dengan nusantara dan sebelum penjajah datang ke nusantara. Pada saat periode ini kerajaan yang berjaya di nusantara, seperti kerajaan Majapahit, Mataram, Kutai, Sriwijaya, dan lainnya. Di bawah kepemimpinan kerajaan pada masa itu aturan yang berlaku ialah yang sesuai dengan kebudayaan serta kepercayaan kerajaan yang berkuasa. Jadi pada saat itu aturan yang diberlakukan sesuai dengan keputusan raja di setiap kerajaan.

Kedua, Periode kolonial, yang dimana negara-negara dari eropa mulai mencoba memasuki dan menduduki nusantara dan mendiami kepulauan-kepulauan di nusantara sejak dari abad 17 sampai dengan Vereenigde Oost Indische Compagnie (VOC) menduduki nusantara. periode ini berjalan sekitar 3,5 abad lamanya, pada masa ini aturan yang diberlakukan adalah hukum Represif in Optima Forma dimana semua hukum tersebut menguntungkan bangsa Belanda dalam hal ini VOC dan sangat merugikan masyarakat di nusantara dalam bidang pertanian dan perekonomian.

Ketiga, Masa Kedudukan Hindia-Belanda. Pada masa ini, daerah jajahan VOC diambil alih oleh pemerintahan Bataafsche Republik pada tahun 1800 dan kemudian namanya diubah menjadi Koninklijk Holland. Pada periode ini pertama kalinya di terbitkan Regeringsreglement atau atau yang lebih dikenal dengan Hindia-Belanda dengan tujuan agar dapat melindungi usaha-usaha yang dilakukan oleh orang Belanda di negara jajahan mereka.

Keempat, Periode Kedudukan Jepang. Jepang mulai menduduki daerah jajahan Hindia Belanda. Pada masa kedudukan Jepang, mereka menjalankan pemerintahan dengan berlandaskan Gunseirei dan pada masa ini tidak banyak perubahan aturan yang terjadi, karena seluruh peraturan yang ada tidak bertentangan dengan Undang-Undang yang mengatur militer Jepang.

Kelima, Periode Kemerdekaan. Hukum di Indonesia menggunakan hukum yang ditetapkan sendiri oleh para pemimpin Indonesia pada saat itu. Pada masa orde lama sejak 18 Agustus 1945 hukum yang berlaku saat itu adalah hukum adat, aturan dalam Islam dan sisa hukum Belanda. Kemudian pada masa reformasi sudah empat kali terjadi amandemen UUD 1945 pada sidang tahunan Majelis Permusyawaratan Rakyat (MPR), dengan begitu susunan UUD 1945 memiliki susunan sebagai berikut: UUD 1945 naskah asli, perubahan pertama UUD 1945 yang ditetapkan pada 19 Oktober 1999, perubahan kedua UUD 1945 yang ditetapkan pada 18 Agustus 2000, perubahan ketiga UUD 1945 yang ditetapkan pada 9 November 2001 , Perubahan keempat UUD 194510 Agustus 2002. 
Setelah kemerdekaan Indonesia, Para founding father Indonesia berkeinginan besar untuk menciptakan dan membentuk hukum nasional sendiri, yang tentunya berlandaskan kepribadian bangsa melalui pembentukan hukum nasional. Pada awal kemerdekaan Indonesia dalam keadaan hukum dan politik yang masih goyah, Indonesia masih terseokseok dalam membentuk aturan yang akan mengatur secara keseluruhan segala bidang kehidupan berbangsa dan bernegara. Demi mencegah terjadinya masa kekosongan hukum, hukum yang ada masih tetap diberlakukan dengan berpedoman pada aturan yang ada.

Pada kurung waktu dari tahun 1945-1959 bangsa Indonesia menjalankan hukum yang cenderung lebih bercorak responsif dengan ciri aspiratif, partisipatif, dan limitatif dikarenakan saat itu demokrasi di Indonesia yang sangat bebas atau lebih dikenal demokrasi liberal sehingga tipologi hukum yang berjalan cenderung ke responsif. Demokrasi yang bebas dalam sistem politik saat itu menciptakan sebuah pengambilan keputusan-keputusan dalam aspek-aspek kebijakan pemerintah lebih dominan dari sebuah proses perwakilan dan atau langsung diberlakukan dengan pembatasanpembatasan supaya keputusan tersebut yang diambil oleh pemerintah melindungi hak-hak individu masyarakat seperti yang termaktub pada konstitusi.

Di masa Orde Baru Pemerintah seringkali melakukan defleksi terhadap UUD 1945. Pada saat itu demokrasi yang berjalan ialah demokrasi terpimpin yang pada akhirnya mengakibatkan terciptanya kepemimpinan otoriter. Dampaknya hukum yang tercipta adalah hukum yang bersifat konservatif, dimana hukum tersebut adalah kebalikan dari hukum responsif, sebab pendapat pemimpin itu sendiri yang dijadikan sebagai landasan dalam terbentuknya produk hukum (Renny NS Koloay, 2016: 18).

Memakai beberapa aturan dan hukum bentukan Belanda sampai saat ini masih tetap dilakukan Indonesia. Namun setelah kemerdekaan Indonesia, berlaku UUD 1945 sebagai dasar konstitusi Indonesia dengan tujuan menunjukan pada dunia bahwa bangsa Indonesia telah merdeka seutuhnya. Kemudian daripada itu, pemberlakuan hukum Belanda hanya semata-mata untuk tidak kosongnya hukum di Indonesia saja karena pada awal kemerdekaan Indonesia belum langsung memiliki aturan dan hukum sendiri. Sebab itu pemerintah sampai saat ini terus melakukan dan membentuk hukum sendiri yang berdasarkan identitas bangsa dengan harapan secara dikit demi sedikit hukum peninggalan Belanda akan tergantikan semua dengan hukum yang dibuat Indonesia sendiri. Dengan begitu mau tidak mau Indonesia akan mengalami perubahan dan perkembangan hukum dalam peraturan hukumnya.

Keberuntungan Indonesia yaitu, para pendahulu telah berhasil meletakan norma dasar 
fundamental negara dengan identitas

kebangsaan, dampak dari itu mengikat

Indonesia untuk menjadikan Pancasila sebagai dasar dari kehidupan bermasyarakat dan sebagai hukum untuk kehidupan berbangsa dan bernegara. Indonesia mempunyai kedudukan yang tetap dan kuat karena Pancasila dijadikan pokok kaidah fundamental bagi Indonesia yang mempunyai dasar-dasar sebuah negara yang tak akan pernah berubah lagi. Berkat Pancasila Indonesia mempunyai hakikat sebuah negara yang berpondasi dan mempunyai implikasi dalam hukum yang baik.

Maka dengan begitu secara keseluruhan aturan dan produk hukum yang dibuat pemerintah tentunya harus mengedepankan dan nilai-nilai Pancasila sebagai dasar fundamental. Sudah sepantasnya dan wajib hukumnya Pancasila dijadikan dasar norma pada semua hirarki perundang-undangan di Indonesia. Teori Hans Kelsen dan Hans Nawiasky sendiri sangat memberikan kontribusi besar pada Indonesia untuk mengawal norma perundang-undangan di Indonesia, teori ini memang seringkali dianggap tidak memberikan ruang untuk kemajuan hukum di Indonesia (Imam Mahdi, 2016: 113). Namun, penulis berpendapat bahwa perkembangan hukum disini hanya berarti sebagai pelengkap pembaruan undang-undang sebagai proses politik saja, yang artinya, hukum merupakan produk dari aktivitas perpolitikan yang digerakkan dengan dalih adanya sebuah kepentingan rakyat yang berdaulat.

\section{Pergeseran Tipologi Hukum Di Indonesia}

Nonet and Selznick, menjelaskan klasifikasi dasar dari hukum yang dijalankan di masyarakat, ada tiga yaitu, sebagai berikut: Pertama, hukum sebagai pelayan kekuasaan yaitu hukum represif; Kedua, hukum sebagai institusi tersendiri yang bisa menjinakkan represi serta melindungi integritas dirinya yang disebut sebagai hukum otonom; Ketiga, hukum sebagai fasilitator dari berbagai respon terhadap kebutuhan dan aspirasi sosial disebut hukum responsif (Henry Arianto, 2001: 118-119).

Nonet dan Selznick juga berpendapat dan menjabarkan, bahwa pada tipe hukum otonom, yaitu semua dijalankan berdasarkan hukum (rule of law) mulai dari sistem pemerintahan yang dijalankan berdasarkan hukum dan kemudian penegakan hukum yang dilakukan oleh aparat harus sesuai dengan apa yang tertulis di dalam aturan hukum yang ada. Pendapat Nonet dan Selznick mengenai tipe hukum otonom ini sejalan dengan apa yang tertulis di Indonesia. Tetapi seringkali hukum di Indonesia justru lebih dekat pada tipe hukum represif, tipe hukum ini memungkinkan orangorang yang mempunyai kuasa secara politik seringkali mempengaruhi dalam pembentukan hukum, mempengaruhi disini demi tercapainya tujuan dan kepentingan mereka. Campur tangan dari para politikus mengakibatkan pembentukan hukum menjadi lebih sempit karena adanya kepentingan mereka saja. Dampaknya bukan 
saja menciptakan rasa tidak adil terhadap masyarakat, adanya hukum seperti itu juga tentu akan menjadi momok bagi kalangan masyarakat itu sendiri.

Pendapat diatas juga diperkuat, bahwa hukum yang ada di Indonesia lebih mendekati represif, karena hukum di Indonesia tidak terlepas dan masih dipengaruhi oleh hukum peninggalan Belanda yang saat ini masih berlaku dengan berbagai tambahan dan pengurangan serta dilengkapi dengan undangundang baru. Jika kita lihat pada masa penjajahan Belanda, hukum tidak dipakai sebagaimana fungsinya yang positif, artiannya yang menjadi tujuan hukum itu sendiri tidak digunakan sebagaimana mestinya. Seperti yang kita ketahui tujuan hukum yaitu memberi keadilan, akan tetapi pada saat itu hukum digunakan sebagai alat untuk penjajah memperkuat posisi mereka dengan tujuan agar adanya legitimasi mereka untuk menghukum para kaum pribumi yang melakukan perjuangan untuk kemerdekaan. Akibatnya, hukum disalahgunakan dan hanya dijadikan alat dari sistem penjajahan yang mengakibatkan hukum tidak memiliki otonominya sendiri. Nonet dan Selznick berpandangan bahwa hukum seperti ini masih berada didalam tahapan tipologi hukum represif (Agus Rahardjo, 2001: 12).

Mochtar Kusumaatmadja dalam satu ungkapannya "hukum tanpa kekuasaan adalah angan-angan, dan kekuasaan tanpa hukum adalah kelaliman" dari ungkapan ini hukum dan kekuasaan itu saling mempengaruhi satu sama lain, khususnya dalam legalisasi kekuasaan dan penegakan hukum, di sisi lain memiliki arti bahwa hukum itu hanya dapat ditegakan dengan kekuasaan dan hukum tidak akan berguna jika tidak ditegakkan, serta kekuasaan tanpa landasan hukum adalah kesewenang-wenangan (Salman Luthan, 2007: 167). Ungkapan tersebut sangat jelas memiliki arti bahwa hukum dan kekuasaan mempunyai hubungan simbiosis yang sangat mempengaruhi satu sama lainnya.

Politik sangat berpengaruh dalam hukum dan prosesnya, yang artinya berlaku juga dalam penegakan hukumnya, karakteristik hukumnya, dan proses terbentuknya hukum. Jika kita lihat dari fungsi hukum sendiri sangat jelas bahwa telah terjadi kemerosotan, hal ini dapat kita dilihat dengan fakta perjalanan hukum di Indonesia. Dimana yang sering kali terjadi penegakkan hukum dan pelaksanaan fungsi hukum tidak selalu berjalan seiringan terhadap perkembangan strukturnya. Jika dilihat dari sudut pandang unifikasi dan kodifikasi hukum memang produktivitas pembentukan hukum di Indonesia mengalami peningkatan dari waktu ke waktu apabila kita lihat dari ukuran pembangunan struktur hukum yang telah berjalan.

Ada tiga perwujudan hubungan antara hukum dengan kekuasaan dalam konteks pembahasan ini (Salman Luthan, 2007: 175176); Pertama, kekuasaan menundukan hukum, dimana hukum sering dijadikan sebagai alat 
untuk berkuasaan, yang artinya kekuasaan memiliki kendali terhadap hukum yang ada. Sebab itu, beberapa ahli mendefinisikan hukum berada di bawah kontrol kekuasaan. Seperti yang disampaikan Thrasymachus, hukum semata-mata hanya bermanfaat untuk orang yang memiliki kekuatan dalam bidang politik dengan kata lain orang yang memiliki kekuasaan. Gumplowicz juga mengungkapkan pendapat yang sama, hukum hanya bersandar pada orang-orang yang kuat untuk menaklukan orang-orang yang lebih lemah. Para penganut ideologi Marxisme juga berpikiran, hukum hanya sebagai alat kaum kapitalis untuk mempermudah kegiatan bisnisnya serta melindungi kepentingannya, dengan kata lain hukum hanya alat penguasa untuk mempertahankan kekuasaannya. Kedua, hukum berada diatas kekuasaan. Hukum merupakan segalanya, kekuasaan taat kepada hukum serta hukum mengendalikan eksistensi kekuasaan. Tunduknya kekuasaan terhadap hukum adalah konsepsi dasar mengenai pemikiran hukum terhadap pelaksana ketatanegaraan. Memiliki arti bahwa hukum ialah kaidah tertinggi dalam mengatur kehidupan bermasyarakat serta bernegara, jika tidak adanya landasan hukum, kekuasaan tidak pernah akan memiliki legalitas. Ketiga, kekuasaan dan hukum saling berhubungan. Pada perwujudan ini, kekuasaan dan hukum memiliki hubungan yang tidak bersifat mendominasi satu sama lain, hubungan pengaruh keduanya bersifat fungsional, hubungan dapat kita lihat dari sudut-sudut fungsi yang ada serta keduanya dapat berjalan beriringan. Dengan begitu, keduanya antara kekuasaan dan hukum mempunyai fungsi yang berjalan dan saling melengkapi dan saling mempengaruhi.

Berkaitan dengan konteks penegakan hukum di Indonesia sudah sangat jelas dan sangat beralasan bahwa tipologi penegakan hukum di Indonesia sudah terjadi pergeseran tipologi yang awalnya masuk dalam tipologi hukum otonom sekarang secara tidak langsung mulai masuk kategori tipe hukum represif. Dimana pembentukan dan penerapan hukum banyak dipengaruhi oleh kepentingan politik dan kekuasaan, kekuasaan dan perpolitik yang otoriter dapat menciptakan hukum yang bersifat represif. Keputusan-keputusan pemerintah di bidang hukum akan lebih banyak berpihak dan bermuatan kepentingan dan visi dari politik penguasa.

\section{SIMPULAN}

Dari hasil pembahasan diatas, dapat ditarik kesimpulan sebagai berikut: Pertama, memakai beberapa aturan dan hukum bentukan Belanda sampai saat ini masih tetap dilakukan Indonesia. Namun setelah kemerdekaan Indonesia, berlaku UUD 1945 sebagai dasar konstitusi Indonesia dengan tujuan menunjukan pada dunia bahwa bangsa Indonesia telah merdeka seutuhnya. Penggunaan hukum peninggalan Belanda hanya untuk agar tidak 
adanya kekosongan hukum di Indonesia dan tentunya Indonesia secara pelan-pelan sudah mewujudkan hukum nasional sendiri. Kedua, Setelah kemerdekaan Indonesia, Para founding father Indonesia berkeinginan besar untuk menciptakan dan membentuk hukum nasional sendiri, yang tentunya berlandaskan kepribadian bangsa melalui pembentukan hukum nasional. Ketiga, Membahas tipologi hukum di Indonesia menurut Nonet dan Selznick, hukum di Indonesia sangat dekat dengan tipe hukum represif dimana pembentukan dan penerapan hukum banyak dipengaruhi oleh kepentingan politik dan kekuasaan, kekuasaan dan berpolitik yang otoriter dapat menciptakan hukum yang bersifat represif. Dampaknya bukan saja menciptakan rasa tidak adil terhadap masyarakat, adanya hukum seperti itu juga tentu akan menjadi momok bagi kalangan masyarakat itu sendiri. Disarankan juga agar pemerintah dalam membuat suatu perundang-undangan agar lebih mengedepankan kepentingan masyarakat banyak dan tentunya harus berpihak pada rakyat-rakyat kecil. Kemudian daripada itu, dalam penegakan hukum harus ditegakan seadil-adilnya tanpa memandang siapa orang yang diadili tersebut, jangan sampai masyarakat berpikir bahwa hukum di Indonesia hanya tajam kebawah saja namun tumpul apabila dihadapkan ke atas.

\section{DAFTAR PUSTAKA}

\section{Buku}

Jimly Asshiddiqie. 2005. Hukum Tata Negara \& Pilar-Pilar Demokrasi Serpihan Pemikiran Hukum, Media dan HAM. Jakarta: Konstitusi Press.

Moh. Mahfud MD. 2009. Konstitusi dan Hukum dalam Kontroversi Isu. Jakarta: Rajawali Pers.

Satjipto Rahardjo. 2005. Ilmu Hukum. Bandung: Citra Aditya Bakti.

Utrecht. 1962. Pengantar Hukum Administrasi Negara Indonesia. Jakarta: Ichtisar.

\section{Jurnal}

Agus Rahardjo, 2001. Fleksibilitas Hukum (Sikap Hukum Menghadapi Perkembangan Jaman), Jurnal Kosmik Hukum, Vol. 1, No. 1.

Henry Arianto, 2010. Hukum Responsif Dan Penegakan Hukum Di Indonesia, Lex Jurnalica Vol. 7 No.2. 
Imam Mahdi, 2016. Ilmu Hukum dan Perkembangannya (Kajian Khusus Hukum Normatif), Jurnal Nuansa Vol. IX, No. 2.

Renny NS Koloay, 2016. Perkembangan Hukum Indonesia Berkenaan dengan Teknologi Informasi dan Komunikasi, Jurnal Hukum Unsrat Vol. 22, No. 5.

Salman Luthan, 2007. Hubungan Hukum dan Kekuasaan, Jurnal Hukum. Vol. 14. No. 2. 